\title{
Article \\ Influence of vacuum brazing temperature on the microstructure of an Inconel 783 superalloy joint with a honeycomb sealing made of Hastelloy $X$ superalloy
}

\author{
Kamil Krystek ${ }^{1}$, Irena Dul ${ }^{1}$, Maciej Motyka2,* \\ ${ }^{1}$ Pratt \& Whitney Rzeszów, Poland \\ Kamil Krystek, M.Sc.; kamil.krystek@pwrze.utc.com; \\ Irena Dul, Ph.D.; irena.dul@pwrze.utc.com; \\ ${ }^{2}$ Rzeszow University of Technology, Poland \\ * Correspondence: Prof. Maciej Motyka; motyka@prz.edu.pl \\ 30.05.2019; Accepted: 29.08.2019
}

\begin{abstract}
The purpose of this work was to assess the influence of brazing temperature on microstructure of the cobalt-based Inconel 783 superalloy joint with nickel-based Hastelloy X superalloy - seal shaped in honeycomb structure. Brazing process was combined with solution heat treatment of Inconel 783 in one operation. Nickel based brazing filler metal from BNi-2 group was used. Tests were conducted in $1121^{\circ} \mathrm{C}$ (solutionizing temperature), $1075^{\circ} \mathrm{C}$ and $1030^{\circ} \mathrm{C}$ in 1 hour. Subsequently, metallographic investigations were made using optical and scanning electron microscopes, mainly focused on changes in a seal made of Hastelloy $X$, where joint erosion in higher temperature was observed.
\end{abstract}

Keywords: Inconel 783; Hastelloy X; vacuum brazing; honeycomb seals

\section{Introduction}

Sealing technology is inextricably linked to industries where fluid flow mechanics play an important role. This problem largely concerns the modern aviation industry, whose domain is to maximize engine performance, while limiting their interference in the natural environment by reducing combustion and emissions of harmful gases. The seals used in aircraft engine turbines deserve special interest because of the extreme operating conditions. The high rotational speed and extremely aggressive environment of exhaust gases determine the use of the latest achievements in the field of machine construction and materials engineering. One of the most modern solutions in this area include the so-called honeycomb seals. They constitute of a type of labyrinth abradable seal (Figs. 1 and 2), whose task is to ensure the smallest possible gap between the rotating turbine elements and the static housing elements cooperating with them. In addition, the specific construction of the honeycomb sealing causes that the flowing gases create vortices inside individual cells, hindering their flow - the phenomenon of so-called dynamic gas sealing [1,2]. This allows to maximize the flow rate of the gas stream in the turbine, thereby increasing its efficiency.

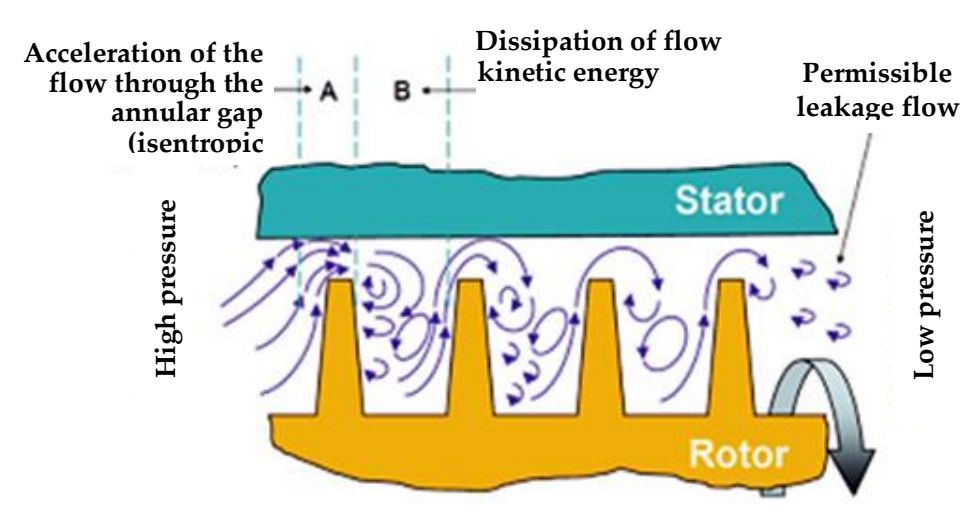

(a)

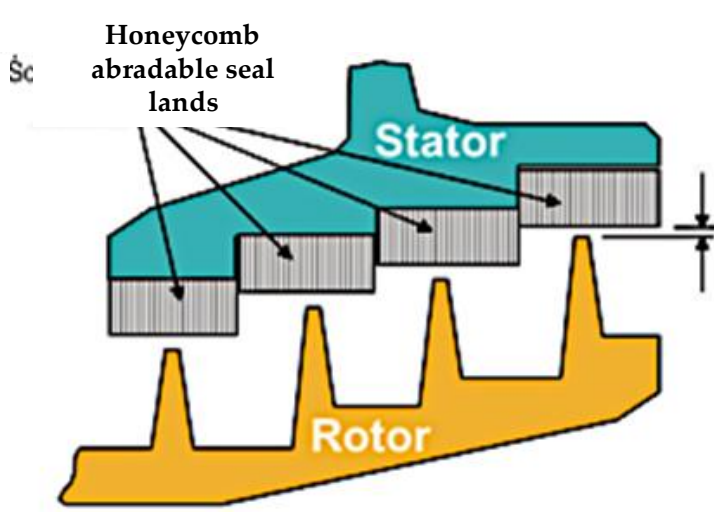

(b)

Fig. 1. a) Diagram of the labyrinth seal and b) an example of the use of a honeycomb seal in a stepped arrangement [5] 
There is also an economic aspect - reduction of leaks in the turbine measurably reduces fuel consumption [3]. As the working temperature increases, the dimensions of the rotating turbine elements increase due to thermal expansion and centrifugal force. That is why turbine assemblies are designed in a way enabling rotor blades, along with increasing their dimensions, to abrade paths in the sealing material without being subjected to mechanical damage [4]. The main criterion for the proper operation of this type of seal is not only a very precise design approach, consisting in the appropriate selection of materials and dimensions of the seal, but also the choice of method and conditions of the technological process of connecting the seal to the housing. For many years, the process of brazing in a vacuum furnace has been irreplaceable in this area [1,4].

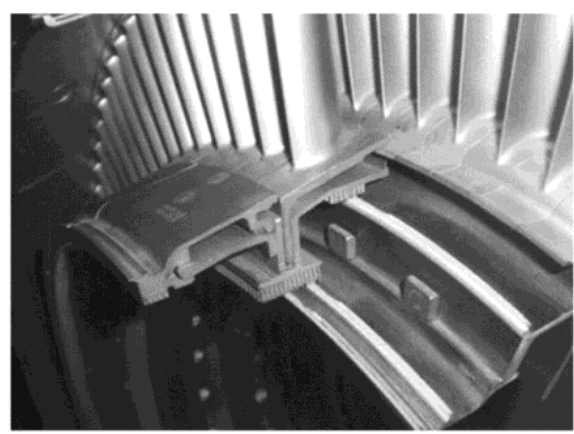

(a)

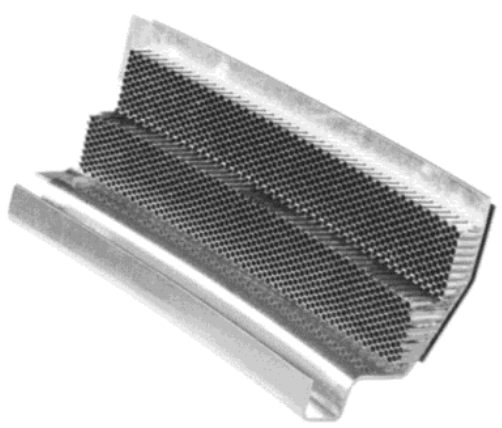

(b)

Fig. 2. Examples of the use of a honeycomb seal: a) sealing between successive turbine stages, b) part of the low turbine housing [5]

\section{Characteristics of materials used in modern turbines}

Inconel 783 is a modern construction material from the group of cobalt superalloys developed by Special Metals Corporation [6]. Its chemical composition consists mainly, in addition to cobalt, nickel and iron, as well as other alloying additions, such as aluminum, niobium and chromium. It has very good oxidation stability up to $704^{\circ} \mathrm{C}$, combined with low thermal expansion. Compared to Inconel 718 - a nickel superalloy used in similar operating conditions - it has a lower coefficient of thermal expansion - by approx. $20 \%$, and a lower density - by approx. 5\%. Inconel 783 is a precipitation-hardened alloy. Optimal mechanical properties are obtained as a result of solutionizing from $1121^{\circ} \mathrm{C}$ after annealing time of 1 hour and multi-stage aging: in the temperature range of $\beta$ phase stability $-845^{\circ} \mathrm{C}$ during 4 hours, rapid cooling to room temperature, subsequent aging at 718 and $621^{\circ} \mathrm{C}$ in a total time of 16 hours. The super alloy in this state is characterized by tensile strength - approx. $1200 \mathrm{MPa}$ at room temperature and approx. $800 \mathrm{MPa}$ at $704{ }^{\circ} \mathrm{C}$. Such strength characteristics make it an excellent material for use in conditions requiring strict dimensional control of

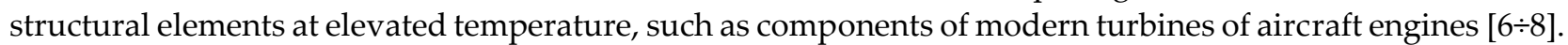
Requirements, including chemical composition (Table I), regarding the use of the Inconel 783 super alloy in the aviation industry are defined by the AMS5940 specification [6].

Honeycomb seals used in aircraft engine turbines are made mainly of Hastelloy X nickel alloy. They are made by welding specially shaped layers of sheet metal with a thickness of tens of micrometers. Finally, a spatial honeycomb structure is obtained in which the cell diameter is usually 0.8 to $3 \mathrm{~mm}$. The sealing height after finishing, depending on the application, is usually in the range of $1.5 \div 13 \mathrm{~mm}$. This design of the seal ensures optimal flow of gases, while guaranteeing that the rotating element cooperating with the seal will not be damaged. The Hastelloy $X$ alloy, from which the seal is made, is subjected to solutionizing from a temperature in the range of $1150 \div 1175{ }^{\circ} \mathrm{C}[1,3]$. Its chemical composition (Tab. II) is defined by the AMS5536 standard [9].

Table I. Chemical composition of the Inconel 783 alloy [5]

\begin{tabular}{lcccccccccc}
\hline \multirow{2}{*}{ Alloy } & \multicolumn{10}{c}{ Average element content [mass \%] } \\
& $\mathrm{Ni}$ & $\mathrm{Fe}$ & $\mathrm{Cr}$ & $\mathrm{Al}$ & $\mathbf{N b}$ & $\mathrm{Ti}$ & $\mathrm{Mn}$ & $\mathrm{Si}$ & $\mathbf{C u}$ & Co \\
\hline Inconel 783 & 28 & 25.5 & 3 & 5.5 & 3 & 0.25 & $\leq 0.5$ & $\leq 0.5$ & $\leq 0.5$ & rest \\
\hline
\end{tabular}

Table II. Chemical composition of the Hastelloy $\mathrm{X}$ alloy [9]

\begin{tabular}{lcccccccccc}
\hline \multirow{2}{*}{ Alloy } & \multicolumn{10}{c}{ Average element content [mass \%] } \\
& Cr & Fe & Mo & Co & W & C & Mn & Si & B & Ni \\
\hline Hastelloy X & 22 & 18 & 9 & 1.5 & 0.6 & 0.1 & $\leq 1$ & $\leq 1$ & $\leq 0.008$ & rest \\
\hline
\end{tabular}


The choice of brazing filler metal (BFM) material is particularly important in the brazing of the honeycomb seal process. Making a good quality brazed joint requires a permanent connection within each sealing cell. It is important that the meniscus formed by BFM, as a result of capillary elevation, is not too high, because hard BFM could cause accelerated wear of the rotating element in contact with the seal. The height of the capillary between the sealing walls must not be too low (Fig. 3), as it will not provide the required stability of the seal during its operation $[4,10]$.

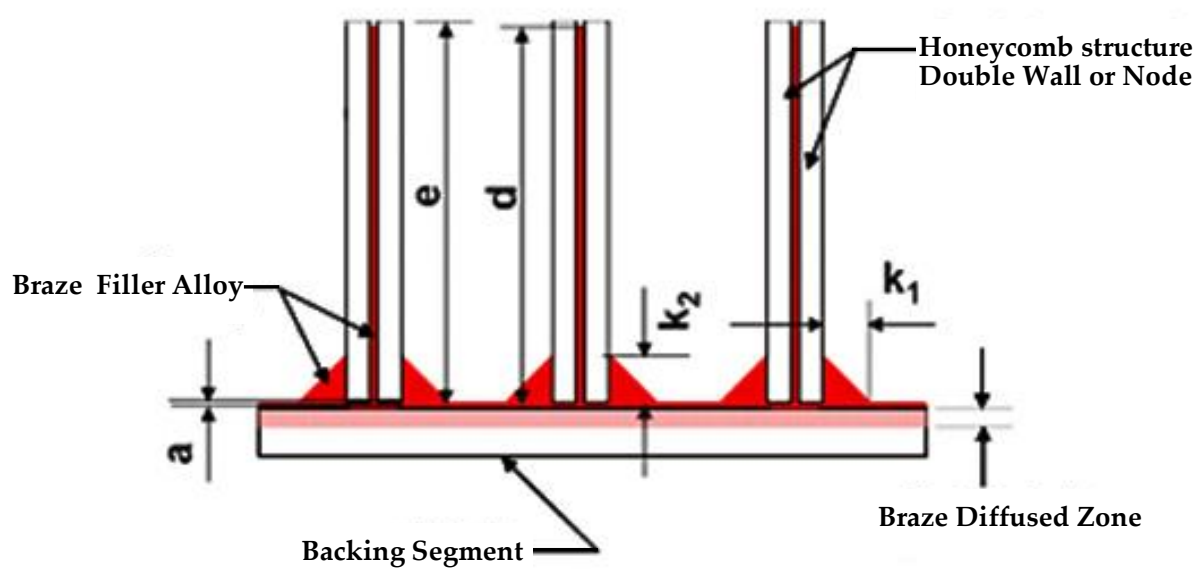

Fig. 3. Geometric characteristics of the correct brazed joint - strives to $d / e>0.8$ [5]

The brazing process requires proper preparation of the surfaces to be bonded, treatments to ensure the right volume and form of the BFM to be delivered, and meticulous visual inspection of all sealed cells. Extremely difficult working conditions of honeycomb seals are fulfilled only by BNi-type braze alloys based on nickel. The most widely used is alloy from the BNi-2 group (according to the American Welding Society nomenclature) described in AMS4777 specification. Joints with its application are characterized by high strength and good corrosion resistance. For brazing of this type of seal, mainly BFM in the form of an elastic tape with a thickness of several tenths of a millimeter and width determined by the width of the seal is used. At the preparatory stage of the process, it is pressed into the honeycomb by rolling. The next stage involves positioning the seal together with applied braze alloy in the housing, usually by resistance spot welding [1,3,4]. The chemical composition and properties of the BFM are presented in table III [11].

Table III. Chemical composition and phase transition temperatures of BNi-2 brazing metal [11]

\begin{tabular}{ccccccccc}
\hline \multirow{2}{*}{ Alloy } & \multicolumn{4}{c}{ Average element content [mass \%] } & \multicolumn{3}{c}{ Temperature [ ${ }^{\circ}$ C] } \\
& Cr & Fe & Si & B & C & Ni & Solidus & Liquidus \\
\hline \multirow{2}{*}{ AWS BNi-2 / AMS4777 } & 7 & 3 & 4.5 & 3.125 & $\leq 0.06$ & reszta & 971 & 999 \\
\hline
\end{tabular}

\section{Purpose and methodology of the research}

The study attempts to assess the impact of brazing temperature on the microstructure of an Inconel 783 cobalt superalloy joint with a Hastelloy $\mathrm{X}$ nickel superalloy in the conditions of the combined brazing process with solutionizing of the Inconel 783 alloy. The research focused on processes occurring in the area of the brazed joint, with particular attention paid to the impact between thin-walled sealing elements and the brazing alloy. The subject of the study were samples of brazed joints of a honeycomb seal on a cobalt superalloy substrate. In accordance with the manufacturer's recommendations regarding solutionizing of the Inconel 783 alloy $\div 1121{ }^{\circ} \mathrm{C}$ after 1 hour - brazing process was performed in this temperature. In addition, other temperature values were also adopted: $1030^{\circ} \mathrm{C}$ - recommended by the brazing alloy manufacturer and $1075^{\circ} \mathrm{C}$ - intermediate. In all cases, a vacuum protective atmosphere, a holding time of 1 hour and rapid cooling were used. Metallographic specimens were made using standard methods, whereas Kalling's reagent was used for etching. Observations of the microstructure of the joints were carried out using a Leica DM2000 light microscope and Hitachi S-3400N scanning electron microscope (SEM) using an accelerating voltage of $20 \mathrm{kV}$. Samples for SEM tests were cleaned in the process of ultrasonic washing. Observations were made using a backscattered electron detector (BSE). In addition, an analysis of the chemical composition in microareas was carried out by means of Energy Dispersive X-ray Spectroscopy (EDS). 


\section{Research results and their analysis}

\section{Light microscopy}

Based on the results of microscopic examination using a light microscope, it was found that in the brazing process the brazing alloy was fully melted and as a result of capillary elevation formed a meniscus on the walls of the honeycomb seal (Fig. 4). The change in the microstructure of the sealing material in the area of contact with BFM indicates the diffusion of alloy components into the parent material. A clearly marked diffusion zone in the base material was identified, suggesting diffusion at grain boundaries, the depth of which increases with increasing brazing temperature. It has been observed that with increasing process temperature, the erosive activity of liquid BFM intensifies, which results in degradation of the honeycomb sealing material (Fig. $4 \mathrm{~b} \div 4 \mathrm{~d}$ ). Conducting the process at $1030^{\circ} \mathrm{C}$ did not result in loss of integrity of the sealing material (Fig. 4a). The darkened area between the walls of the honeycomb that is difficult to analyze will be subjected to more detailed analysis based on the results of SEM tests. Analysis of the results of light microscopy shows that an increase in the brazing temperature results in greater degradation of the sealing material in the joint area (Fig. 5).

As a result of brazing at $1075{ }^{\circ} \mathrm{C}$ (Fig. 5b), near the base material, the walls of the seal were eroded partially dissolved due to the aggressive activity of a molten BFM. This leads to a decrease in the crosssectional area of the sealing walls and, as a result, weakens the joint.

Brazing at $1121{ }^{\circ} \mathrm{C}$ intensifies the phenomenon of destruction of the sealing material: from partial dissolution of the walls and the creation of a uniform alloying zone with the brazing alloy material next to the substrate (Fig. 5c), to advanced degradation, causing loss of connection with the substrate (Fig. 5d).

\section{SEM/EDS tests}

\section{Joint brazed at a temperature of $1030^{\circ} \mathrm{C}$}

In the joint made at $1030^{\circ} \mathrm{C}$, no damage to the honeycomb sealing material was found (Fig. 6). Chemical composition analysis was performed in selected areas (Fig. 7a) (Tables IV and V).

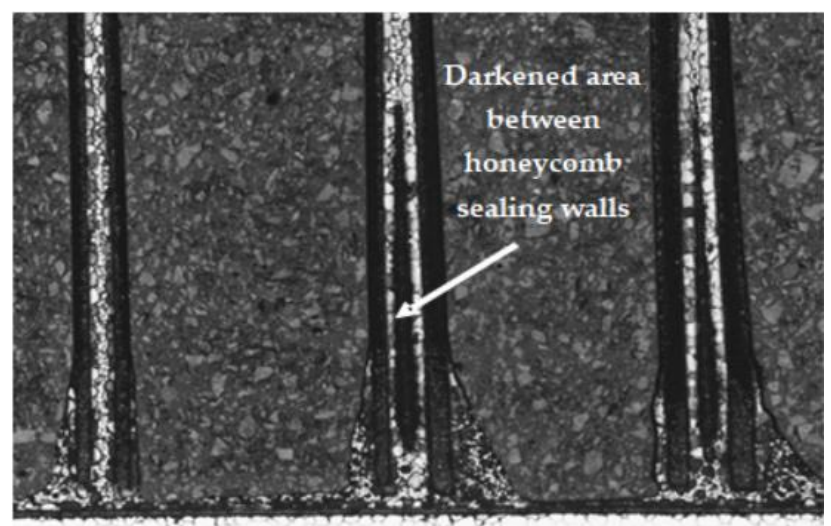

$500 \mu \mathrm{m}$

(a)

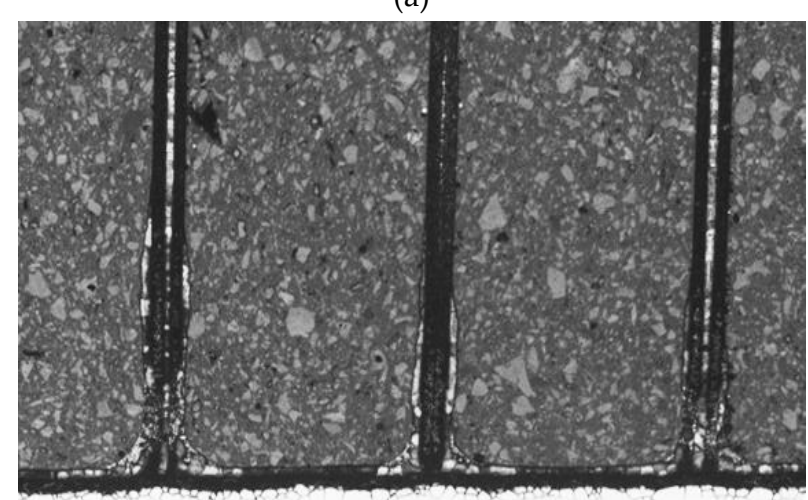

$500 \mu \mathrm{m}$

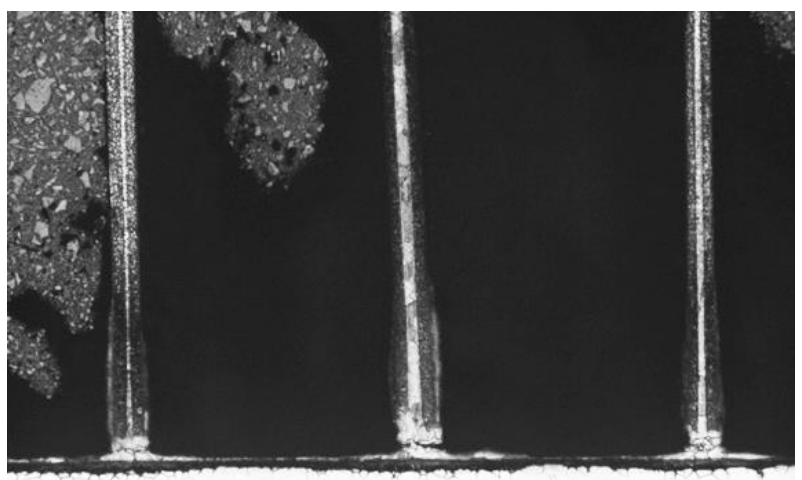

$500 \mu \mathrm{m}$

(b)

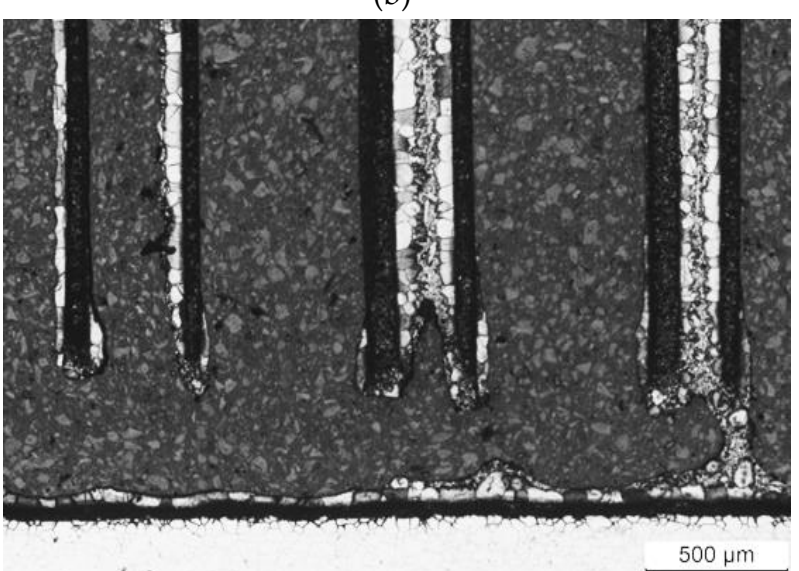

(d)

Fig. 4. Microstructure of the joint brazed at a temperature of: a) $1030^{\circ} \mathrm{C}$, b) $1075^{\circ} \mathrm{C}$ and c, d) $1121^{\circ} \mathrm{C}$ 


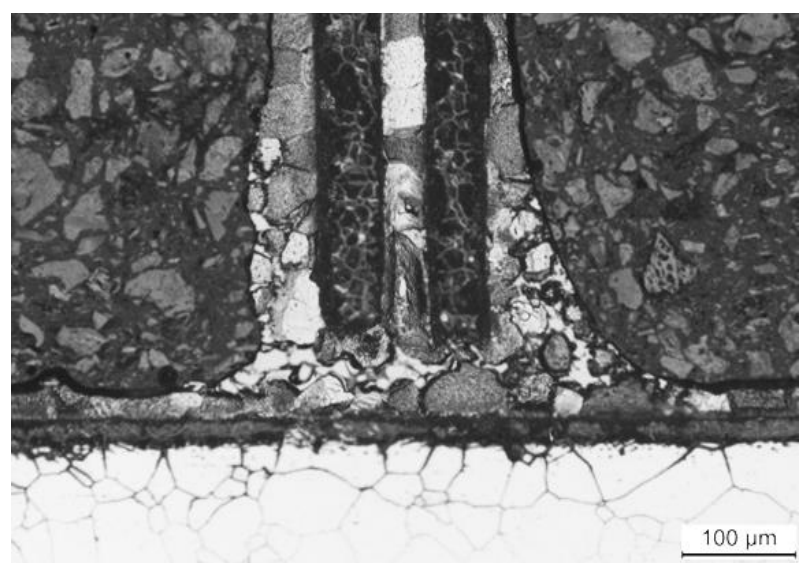

(a)

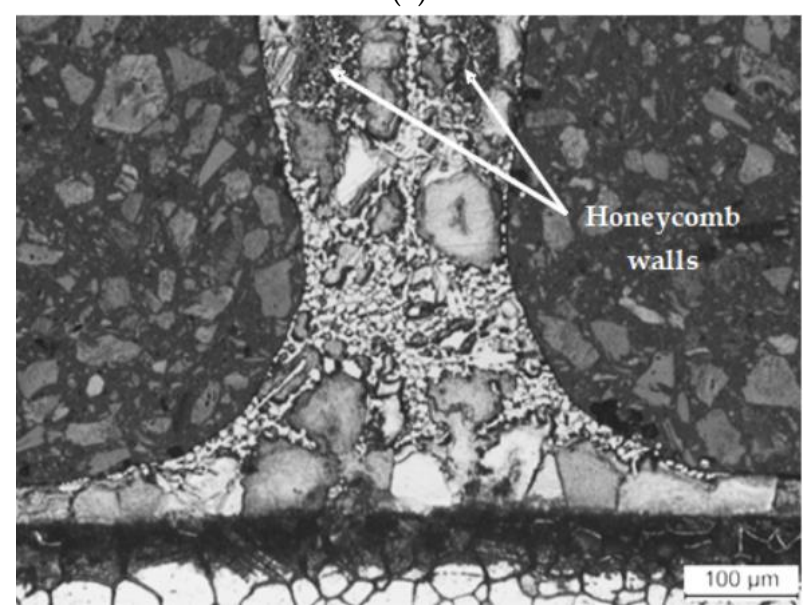

(c)

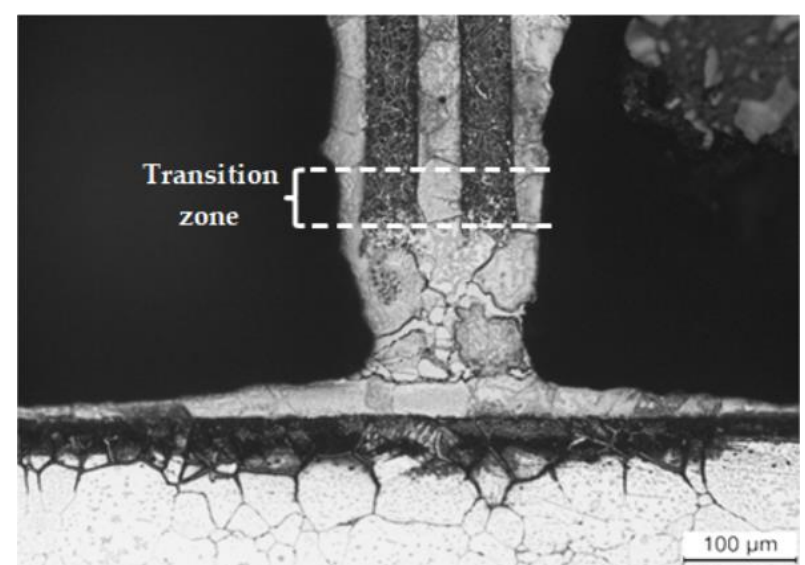

(b)

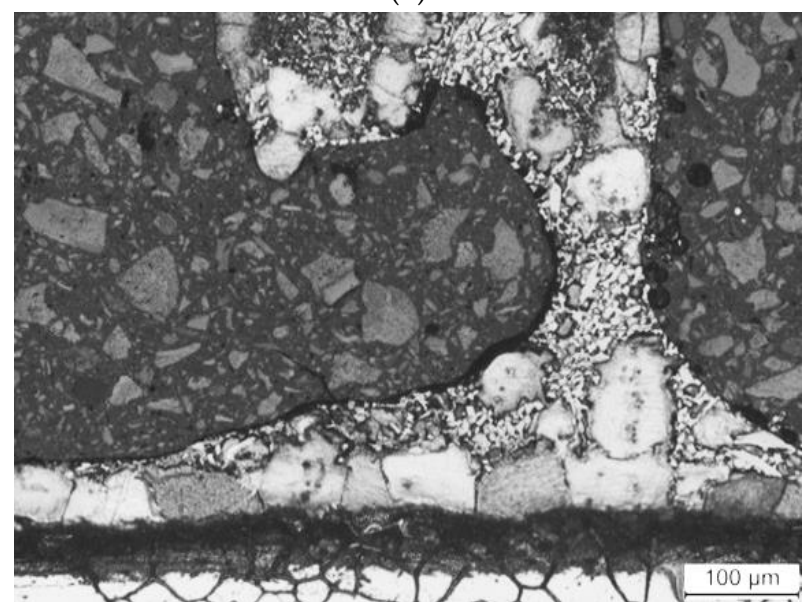

(d)

Fig. 5. Microstructure of the joints brazed at a temperature of: a) $1030^{\circ} \mathrm{C}$-intact sealing material, b) $1075^{\circ} \mathrm{C}-$ traces of erosion of the sealing material near the substrate and visible transition zone, $\mathrm{c}$ and d) $1121^{\circ} \mathrm{C}-$ advanced erosion of the honeycomb sealing material, with partial loss of continuity of the joints (d)

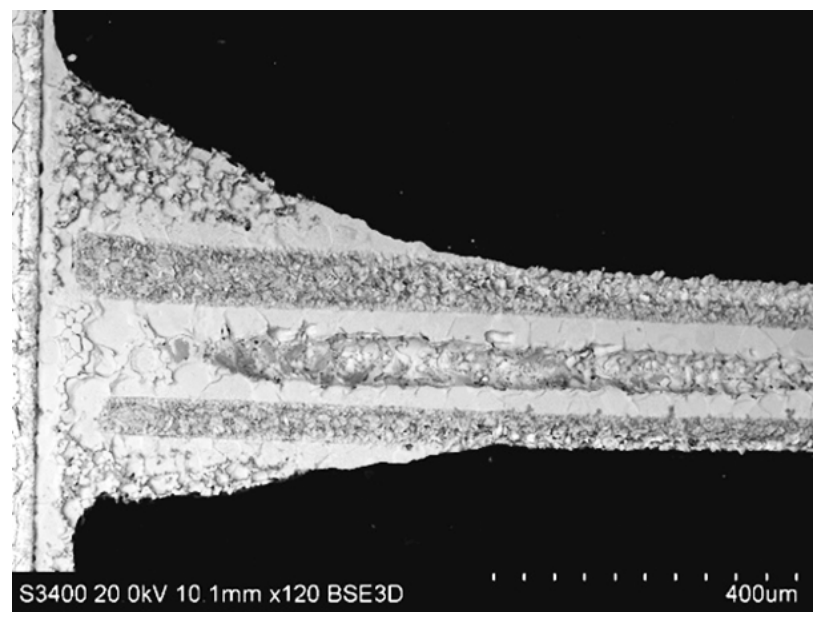

(a)

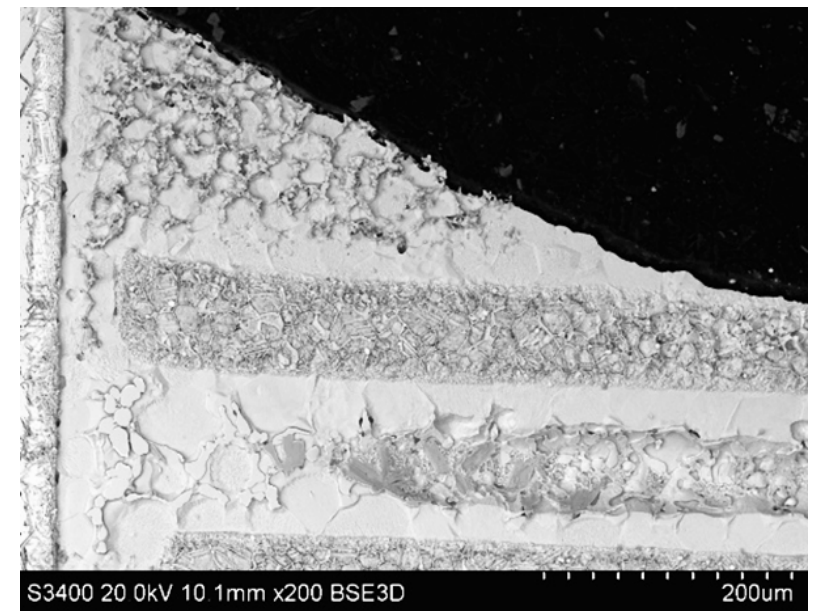

(b)

Fig. 6. Microstructure of the joint brazed at a temperature of $1030{ }^{\circ} \mathrm{C}$

Table IV. Chemical composition in micro-areas $1 \div 5$ shown in Figure 7 a

\begin{tabular}{cccccccc}
\hline \multirow{2}{*}{ Area } & \multicolumn{7}{c}{ Element content [mass \%] } \\
& Si-K & Cr-K & Fe-K & Co-K & Ni-K & Mo-L & W-L \\
\hline 1 & 1.9 & 29.9 & 3.2 & 0.4 & 64.7 & - & - \\
2 & 3.6 & 9.6 & 5.9 & - & 80.9 & - & - \\
3 & - & 54.4 & 8.2 & 0.8 & 9.0 & 25.3 & 2.2 \\
4 & 5.0 & 17.9 & 2.1 & - & 73.8 & 1.2 & - \\
5 & 3.7 & 8.9 & 5.4 & - & 82.0 & - & - \\
\hline
\end{tabular}


Table V. Chemical composition in micro-areas 1 $\div 5$ shown in Figure 7b

\begin{tabular}{ccccccc}
\hline \multirow{2}{*}{ Area } & \multicolumn{6}{c}{ Element content [mass \%] } \\
& Si-K & Cr-K & Mn-K & Fe-K & Ni-K & Mo-L \\
\hline 1 & 13.0 & 3.8 & - & 1.6 & 81.5 & - \\
2 & 0.8 & 5.6 & 0.7 & 1.9 & 91.0 & - \\
3 & - & 88.8 & - & 0.8 & 5.1 & 5.3 \\
4 & 3.1 & 6.1 & 0.5 & 3.9 & 86.4 & - \\
5 & - & 5.2 & - & 2.1 & 92.6 & - \\
\hline
\end{tabular}

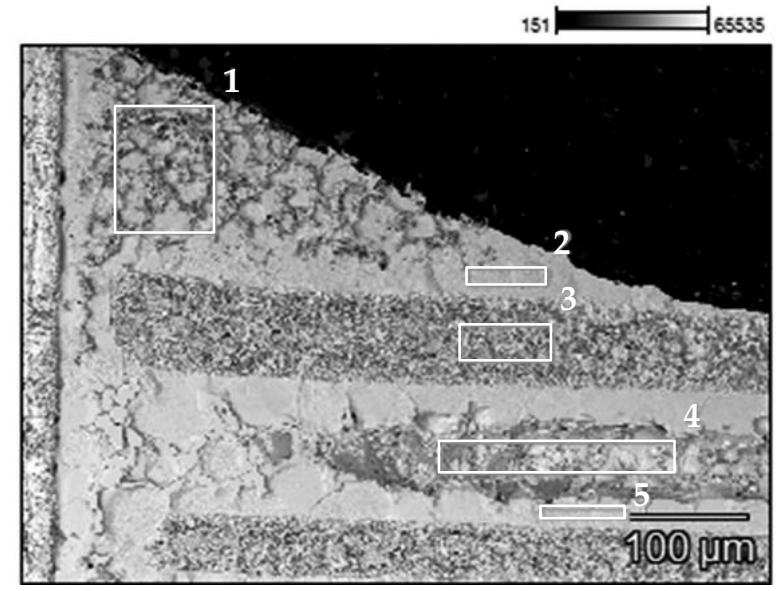

(a)

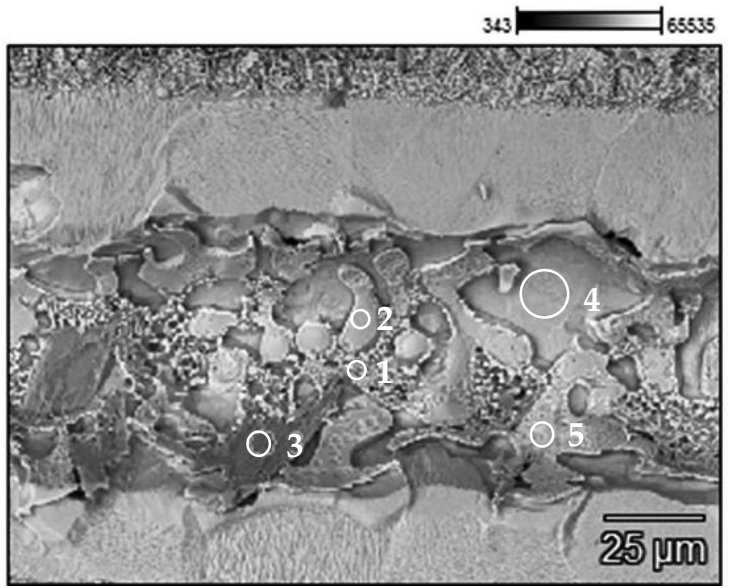

(b)

Fig. 7. a) Micro-areas of chemical composition analysis of the joint brazed at a temperature of $1030{ }^{\circ} \mathrm{C}$ and b) in the space between the walls of the hive cell, inside the area 4

Analysis of changes in the concentration of nickel, chromium, silicon and iron in the area of the joint confirms the occurrence of diffusion between the substrate material, sealing and solder (Fig. 7, Table IV). Chromium and nickel-rich phases were found in the area adjacent to the substrate material. Between the sealing walls, an area separated by a clear interface can be distinguished, characterized by a different chemical composition compared to the surrounding BFM (Table V). The chemical composition found indicates the possibility of silicon-rich phases, which is also confirmed by point analysis carried out at higher magnification (Fig. 7b). Due to the presence of melting point depressants in brazing alloy the precipitation of such phases under specific conditions is typical for the brazing process using material from the BNi-2 group. These phases are characterized by high hardness and brittleness, which is why this is an undesirable phenomenon, which should be prevented by appropriate selection of process conditions [3].

The linear distribution of elements (Fig. 8) indicates that the dominant component of the matrix of crystallized BFM is nickel, the concentration of which decreases within the sealing walls and the precipitation zone between them (darkened area between the sealing walls - Fig. 4a). In these areas, increased chromium content and reduced iron concentration are observed.

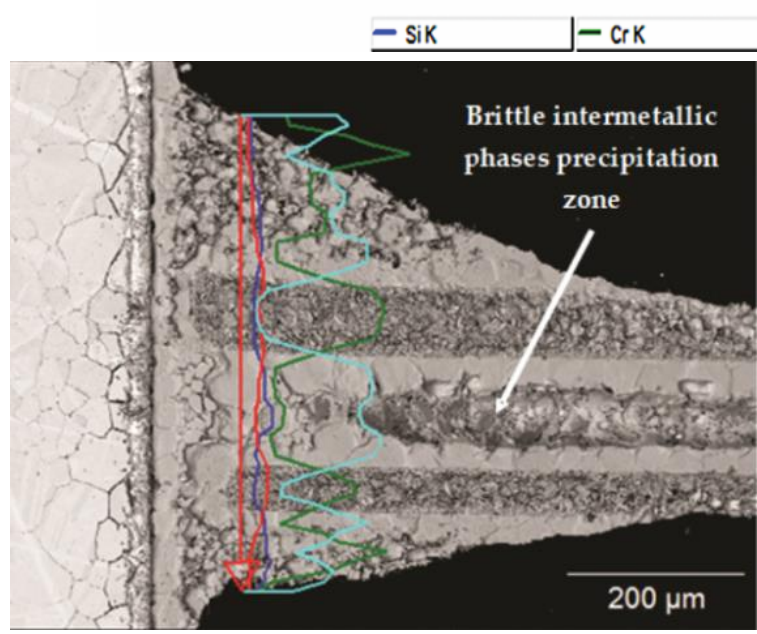

(a)

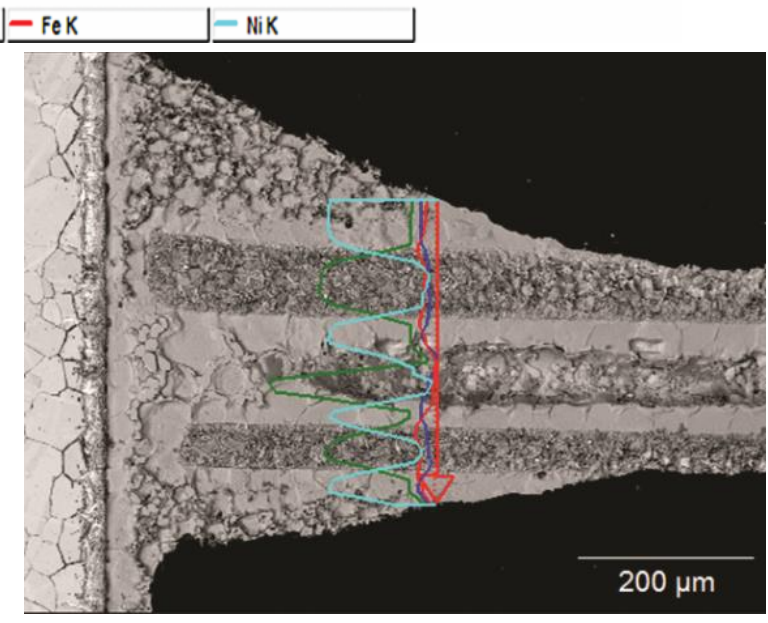

(b)

Fig. 8. Linear distribution of elements in the area of the joint brazed at a temperature of $1030{ }^{\circ} \mathrm{C}$ 
The precipitation zone between the sealing walls is most likely made of brittle intermetallic phases [12]. Chemical analysis in the area of the sealing material (Fig. 7a, area 3) did not show the presence of silicon. Increased silicon concentration was noted in area 4 (Fig. 7a). Distribution of this element in the joint indicates that the process conditions were not sufficient for its effective diffusion into the sealing material. As a result, a precipitation zone consist of silicon-rich phases was formed between the cell walls.

\section{Joint brazed at a temperature of $1075{ }^{\circ} \mathrm{C}$}

The joint brazed at a temperature of $1075^{\circ} \mathrm{C}$ is characterized by advanced degradation of the sealing cells (Fig. 9). Three characteristic areas can be distinguished on its cross-section. The area closest to the substrate is the area in which the seal has completely dissolved - its microstructure appears to be singlephase, with few pores. In the next area, the seal was partially dissolved, while above it the honeycomb seal was not damaged. In the discussed joint there was no presence of the brittle phase precipitation zone observed in the joint brazed at a lower temperature $\left(1030^{\circ} \mathrm{C}\right)$. In all areas, chemical composition analysis was performed in micro-areas (Fig. 10a), as well as point analysis (Fig. 10b), the results of which are presented in table VI and table VII, respectively.

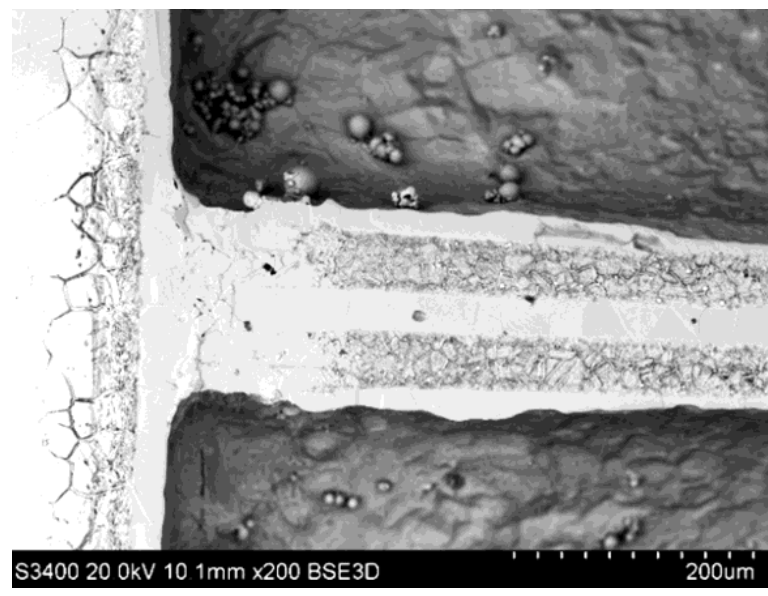

(a)

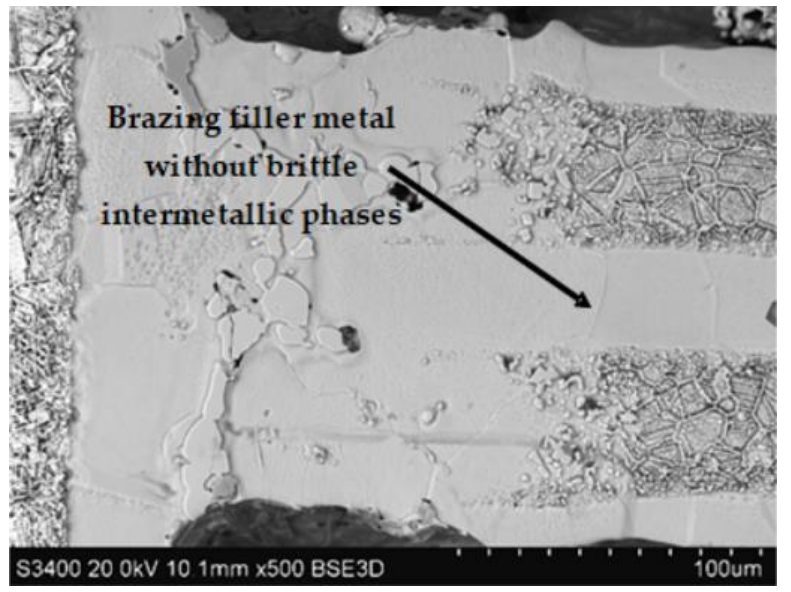

(b)

Fig. 9. Microstructure of the joint brazed at a temperature of $1075^{\circ} \mathrm{C}$

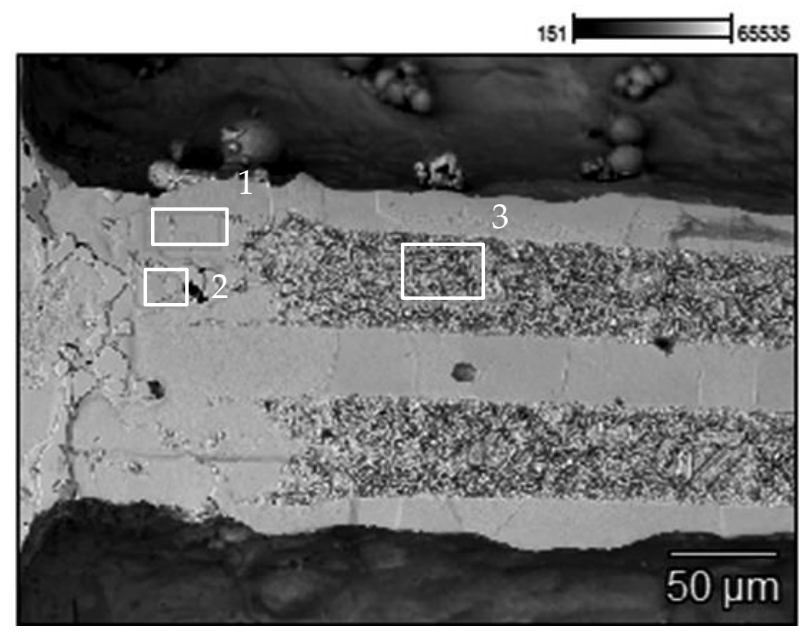

(a)

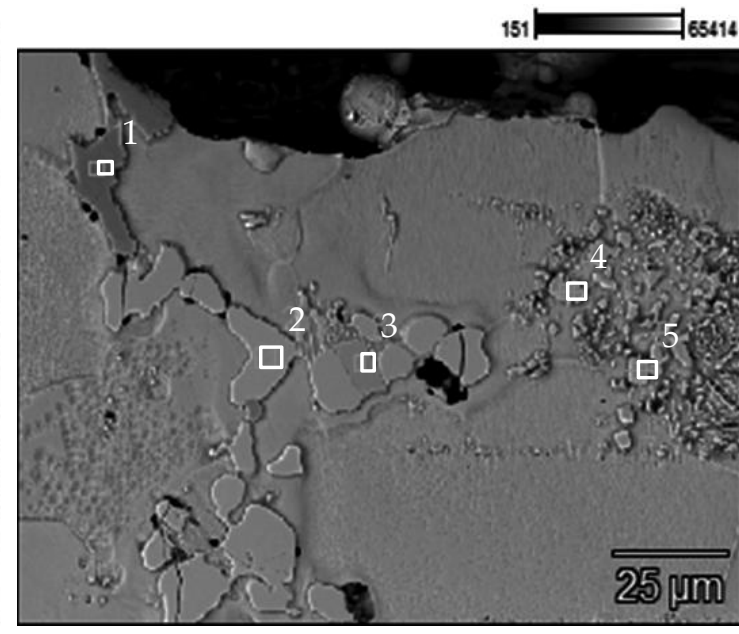

(b)

Fig. 10. Micro-areas of the analysis of the chemical composition of a joint brazed at a temperature of $1075^{\circ} \mathrm{C}$

Table VI. Chemical composition in micro-areas $1 \div 3$ shown in Figure 10a

\begin{tabular}{cccccccc}
\hline \multirow{2}{*}{ Area } & \multicolumn{7}{c}{ Element content [mass \%] } \\
& Si-K & Cr-K & Mn-K & Fe-K & Co-K & Ni-K & Mo-L \\
\hline 1 & 3.8 & 10.2 & & 6.2 & 0.9 & 78.8 & \\
2 & 3.2 & 16.1 & & 3.5 & 1.0 & 76.2 & \\
3 & 0.9 & 31.7 & 0.5 & 14.4 & 1.2 & 36.0 & 15.2 \\
\hline
\end{tabular}


Analysis of the chemical composition in the area adjacent to the base material (Fig. 10a, areas 1 and 2) indicates that the components of its microstructure contain chromium, molybdenum and nickel. This area is homogeneous in terms of chemical composition, which is confirmed by similar results of point analysis (Table VI).

Table VII. Chemical composition in micro-areas 1 $\div 5$ shown in Figure 10b

\begin{tabular}{cccccccc}
\hline \multirow{2}{*}{ Area } & \multicolumn{7}{c}{ Element content [mass \%] } \\
& Si-K & Cr-K & Fe-K & Co-K & Ni-K & Mo-L & W-L \\
\hline 1 & 0.7 & 83.2 & & & & 16.1 & \\
2 & & 5.2 & 2.8 & 1.5 & 90.5 & & \\
3 & & 57.8 & 2.7 & 0.9 & 13.9 & 22.0 & 2.7 \\
4 & & 55.1 & 2.7 & 0.6 & 13.6 & 22.9 & 5.1 \\
5 & & 55.3 & 2.9 & 0.8 & 13.4 & 23.2 & 4.4 \\
\hline
\end{tabular}

Based on the analysis of the linear distribution of elements in the area near the substrate (Fig. 11a), no significant differences in chemical composition were found in the cross-section. The observed changes are local and result from the presence of individual components of the microstructure. The next area (Fig. 11b) is characterized by a step change in nickel and chromium concentration - typical for the solder-seal interface. This indicates the presence of residues of dissolved honeycomb sealing in this area. The distribution in the zone of the intact sealing material (Fig. 11c) results from the different chemical composition of brazing alloy and parent material. It also confirms the absence of brittle phases in the area between the sealing walls.

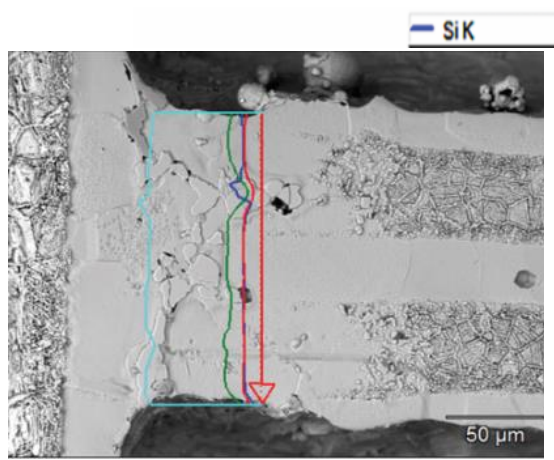

(a)

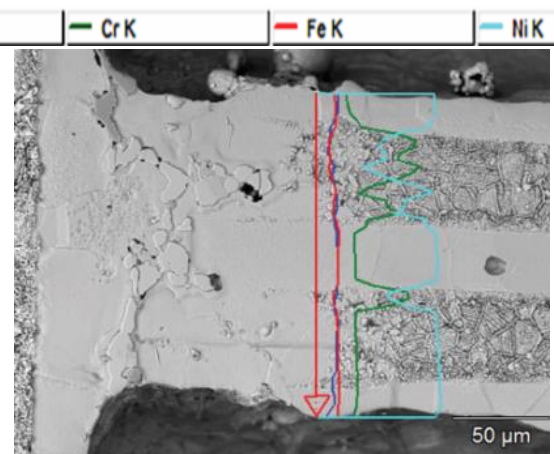

(b)

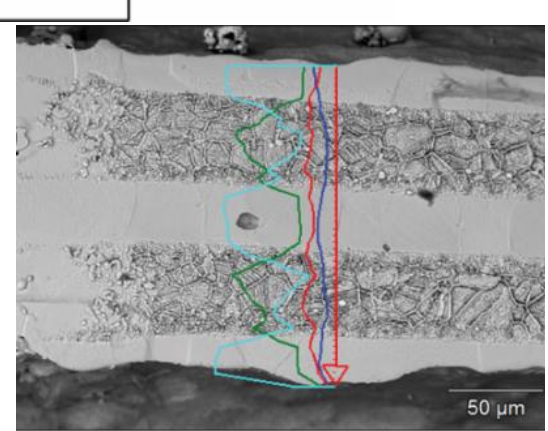

(c)

Fig. 11. Linear distribution of elements in the area of the joint brazed at a temperature of $1075{ }^{\circ} \mathrm{C}$

\section{Joint brazed at a temperature of $1121{ }^{\circ} \mathrm{C}$}

The sealing brazed at a temperature of $1121^{\circ} \mathrm{C}$ was degraded the most. Near the substrate, where the sealing cells were completely dissolved, a necking is visible with characteristic, fine-grained precipitations (Fig. 12b). Above the necking, in a place corresponding to the original location of the sealing walls, their residues forming a mixture with BFM were observed (Fig. 12a). Further away from the substrate surface, undamaged walls separated by a zone of crystallized BFM with a homogeneous microstructure were identified (Fig. 13b).

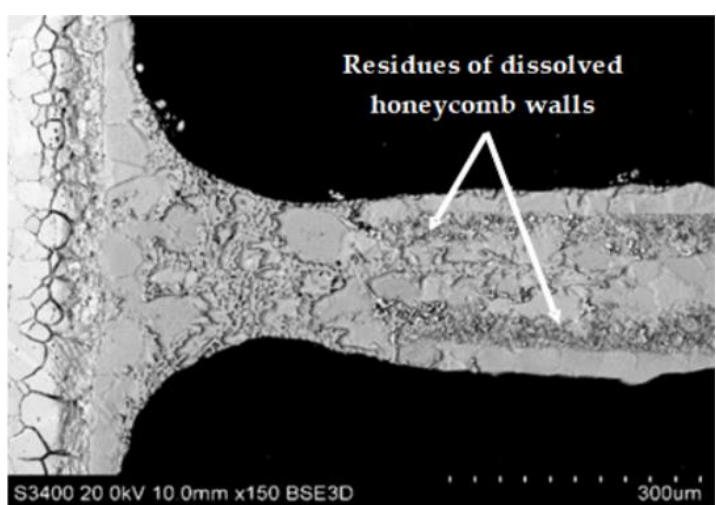

(a)

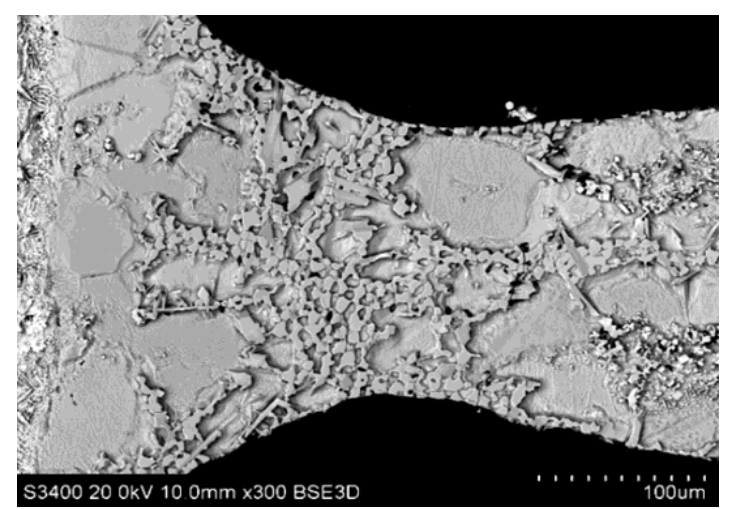

(b)

Fig. 12. Microstructure of the joint brazed at a temperature of $1121^{\circ} \mathrm{C}$ 
The analysis of the chemical composition of the joint brazed at $1121^{\circ} \mathrm{C}$ was carried out in five characteristic areas (Fig. 13a). Almost identical chemical composition was found in micro-areas 1, 3 and 4, suggesting that they represent the same microstructure component. In micro-area 2, an increased nickel content was found with a reduced chromium content. The largest differences in the chemical composition were found in the zone of very fine grains in area 5, where the concentration of nickel and iron was twice lower compared to other microareas, while the content of molybdenum and tungsten was higher (Table VIII).

In the case of a joint brazed at $1121^{\circ} \mathrm{C}$, an analysis of the linear distribution of elements was performed in four areas (Fig. 14). The microstructure closest to the base material is homogeneous with single phase precipitations with increased chromium content (Fig. 14a). In the necking area (Fig. 14b), where the dominant constituent of the microstructure are precipitations of complex morphology, significant changes in the concentration of nickel, chromium and silicon were found. In the next area (Fig. 14c) the distribution is similar to the one in the joint brazed at $1075{ }^{\circ} \mathrm{C}$. The last distribution (Fig. 14d), analogous to the other joints, illustrates the differences in the chemical composition of BFM and parent material.

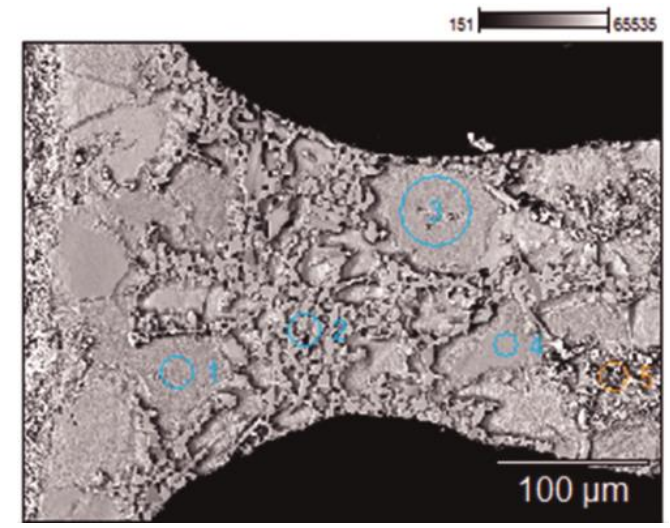

(a)

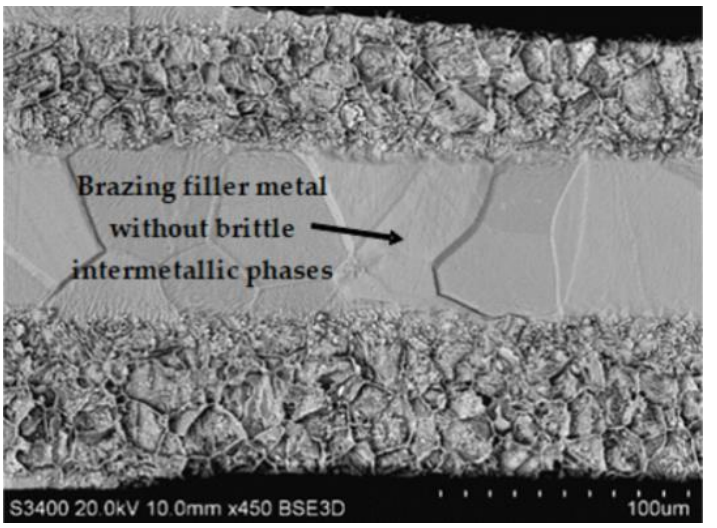

(b)

Fig. 13. a) Micro-areas of the chemical composition analysis of the joint brazed at a temperature of $1121{ }^{\circ} \mathrm{C}$ and b) the microstructure in the area above the seal material degradation zone

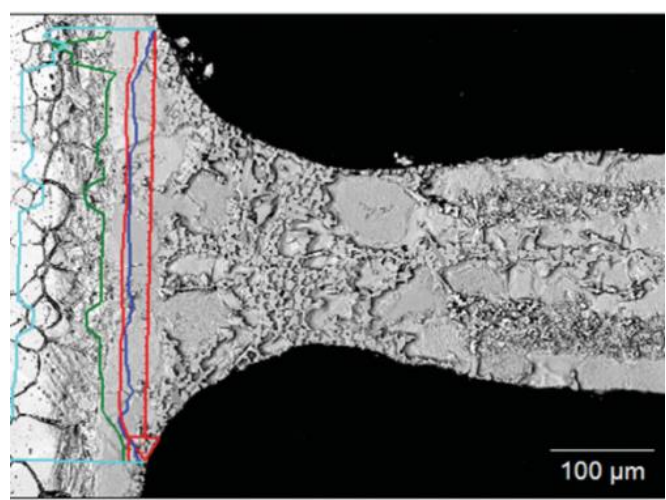

(a)

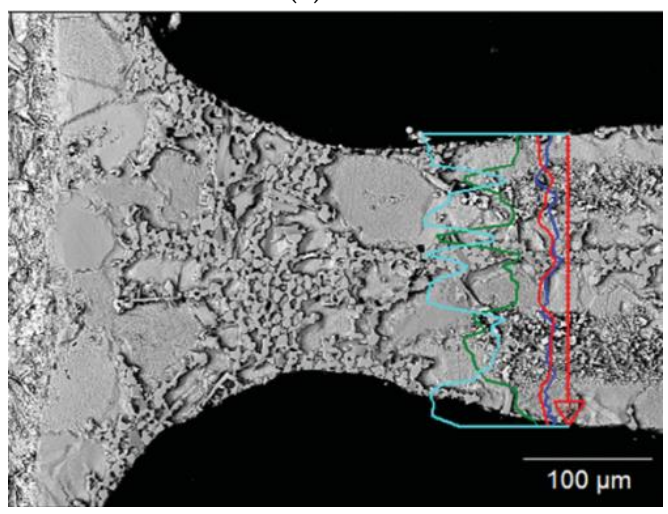

(c)

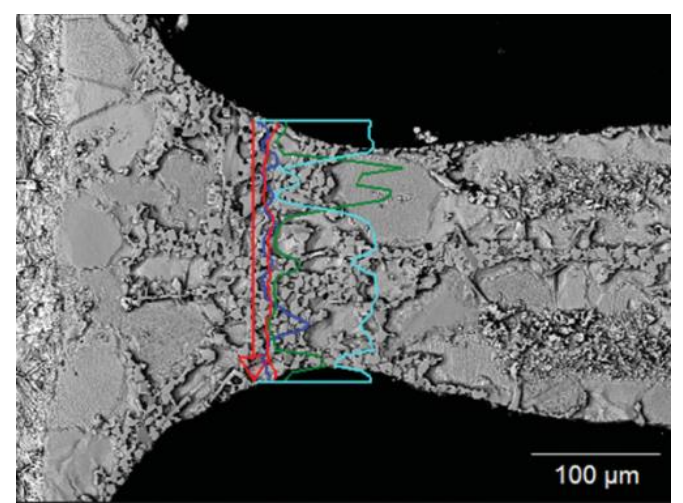

(b)

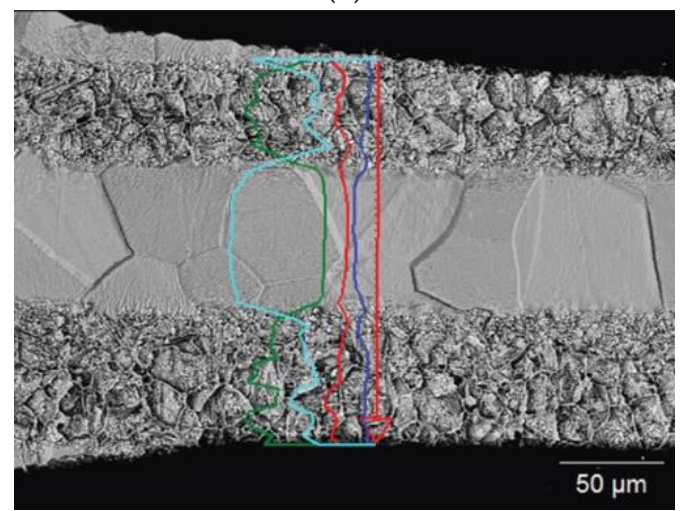

(d)

- $\mathrm{SiK} \quad$ -

Fig. 14. Linear distribution of elements in the area of the joint brazed at a temperature of $1121^{\circ} \mathrm{C}$ 
Tables VIII. Chemical composition in micro-areas 1 $\div 5$ shown in Figure 13a

\begin{tabular}{ccccccccc}
\hline \multirow{2}{*}{ Area } & \multicolumn{7}{c}{ Element content [mass \%] } \\
& Si-K & Cr-K & Mn-K & Fe-K & Co-K & Ni-K & Mo-L & W-L \\
\hline 1 & 3.0 & 12.4 & - & 8.6 & 1.9 & 72.9 & 1.1 & - \\
2 & 4.0 & 5.4 & 1.0 & 3.9 & 1.7 & 83.9 & - & - \\
3 & 3.0 & 12.7 & 0.3 & 8.2 & 1.9 & 72.5 & 1.5 & - \\
4 & 2.9 & 11.9 & 0.4 & 8.4 & 1.7 & 73.5 & 1.1 & - \\
5 & - & 33.1 & - & 4.7 & 1.3 & 36.7 & 17.3 & 6.9 \\
\hline
\end{tabular}

\section{Summary}

The impact of a vacuum brazing temperature on the microstructure of a joint between honeycomb seal made of Hastelloy X superalloy with a turbine housing made of Inconel 783 superalloy was studied. Brazing tests were carried out in a vacuum atmosphere at $1121^{\circ} \mathrm{C}$ - cobalt alloy solutionizing temperature - as well as 1075 and $1030^{\circ} \mathrm{C}$ for 1 hour. Based on analysis of the obtained test results it was found that increasing of brazing temperature causes an increase in the degree of degradation of thin-walled honeycomb sealing material due to erosion, causing even loss of continuity of its connection with the substrate - housing. Analysis of the linear distribution of elements in the joint showed that during brazing at $1030{ }^{\circ} \mathrm{C}$, phases were formed in the brazing filler metal area between the sealing walls - which appear to be brittle intermetallic compounds, reducingthe strength of the joints. In the case of joints brazed at 1075 and $1121{ }^{\circ} \mathrm{C}$, these phases were not observed in the area outside the erosion zone within the joint between the sealing walls. The high temperature of the process and the relatively long brazing time resulted in the homogenization of the microstructure. The silicon content found in the sealing material area suggests its diffusion from brazing alloy. In the joint brazed at $1030{ }^{\circ} \mathrm{C}$ this phenomenon was not observed, which is due to the lower temperature of the process. The summary concludes that it is not possible to combine honeycomb brazing and solutionizing of Inconel 783 in one technological process. In brazing conditions at solutionizing temperature $-1121^{\circ} \mathrm{C}$ - the phenomenon of sealing erosion is very intense and, as a consequence, causes loss of joint continuity. During brazing at $1075{ }^{\circ} \mathrm{C}$, the erosion intensity is lower, but its effects are still unacceptable. It makes sense to shorten the brazing time, which should result in minimizing the process of dissolving the parent material of sealing by liquid brazing alloy. Brazing at $1030{ }^{\circ} \mathrm{C}$-recommended for the accepted solder - leads to the correct joint without any signs of erosion. However, such conditions favor the formation of intermetallic phases in the joint microstructure, the presence of which reduces its strength.

Author Contributions: conceptualization K.K. and I.D.; methodology K.K., I.D. and M.M.; investigation K.K. and M.M.; writing-original draft preparation K.K. and I.D.; writing-review and editing K.K. and M.M.; supervision M.M.;

Conflicts of Interest: The authors declare no conflict of interest.

\section{References}

[1] Babul T., Jakubowski J., Kopeć J., Kowalski S., Senkara J., Turowska L., Lutowanie próżniowe uszczelnień ulowych w aparatach kierujących wykonanych ze stopów Hastelloy i Inconel z zastosowaniem lutu NiCrSiB. Welding Technology Review, 2007, Vol. 79(9), 124-129.

[2] Zhang L., He L., Hu H., Feng H., Honeycomb seal technology achieves superior sealing effect in centrifugal air compressor - Part I. Sealing Technology, 2018, Vol. 2018(7), 8-10. [CrossRef]

[3] Collins D., Teixeira J., Crudgington P., The degradation of abradable honeycomb labyrinth seal performance due to wear. Sealing Technology, 2008, Vol. 2008(8), 7-10. [CrossRef]

[4] Kay D., Honeycomb-brazing essentials for successful use as turbine seals. Industrial Heating, 2003, Vol. 70(11), 33-37.

[5] Sporer D., Fortuna D., Selecting materials for brazing a honeycomb in turbine engines. Welding Journal, 2014, Vol. 93(2), 44-48.

[6] Special Metals, online: http://www.specialmetals.com/assets/smc/documents/ alloys/inconel/inconel-alloy-783.pdf (access date 08.05.2019).

[7] Kang B., Liu X., Cisloiu C., Chang K-M., High temperature moire interferometry investigation of creep crack growth of Inconel 783/environment and $\beta$-phase effects. Materials Science and Engineering: A, 2003, Vol. 347(1-2), 205-213. [CrossRef] 
Ma L., Chang K-M., Effects of different metallurgical processing on microstructures and mechanical properties of Inconel alloy 783. Journal of Materials Engineering and Performance, 2004, Vol. 13(1), 32-38. [CrossRef]

[8] Haynes International. http://www.haynes.ch/doc/HASTELLOY_X.pdf (08.05.2019),

[9] Baranowski J., Breliński J., Boretius M., Lutowanie części szczególnie odpowiedzialnych spoiwem AMS4777 (BNi2). Welding Technology Review, 2007, Vol. 79(9), 22-25.

[10] Prince \& Izant Company. https://pi.rifdigital.com/uploads/ Tech_Data_Sheets/Nickel_Tech_Data_Sheets/AMS_ 4777_BNi-2_TDS.pdf (access date 08.05.2019).

[11] American Welding Society (AWS) C3 Committee on Brazing and Soldering. Brazing Handbook, 5th ed.; American Welding Society: Miami FL, United States of America, 2007, 164.

(C) 2019 by the authors. Submitted for possible open access publication under the terms and conditions of the Creative Commons Attribution (CC BY) license (http://creativecommons.org/licenses/by/4.0/). 